\title{
PENTINGNYA MENGETAHUI PERBEDAAN HARGA POKOK PENJUALAN PERUSAHAAN DAGANG DAN MANUFAKTUR
}

\author{
Sofia Prima Dewi ${ }^{1}$ dan Jocevine Angela ${ }^{2}$ \\ ${ }^{1}$ Jurusan Akuntansi, Universitas Tarumanagara \\ Email: sofiad@fe.untar.ac.id \\ 2 Jurusan Akuntansi, Universitas Tarumanagara \\ Email: Jocevine888@gmail.com
}

\begin{abstract}
The problem faced by partners, namely the Dharma Pembangunan Scholarship Institute, is that students do not have a deep understanding of topics regarding cost of goods sold, even for trading companies and manufacturing companies, and determine important cost of goods sold. Lecturers of the Faculty of Economics and Business, Tarumanagara University offer a solution by providing training on the cost of goods sold in trading companies, when to cost products, total manufacturing costs, manufacturing production costs, and making the cost of goods sold in manufacturing companies. The target of this training is for the students of the Dharma Pembangunan Scholarship Institute to understand the cost of goods sold in trading and manufacturing companies. First, a survey was conducted and based on the survey, in order to discuss the material on the cost of goods sold in trading and manufacturing companies. The topic this time is a continuation of previous community service activities. Students have received different topics from the previous training. Furthermore, the lecturer prepares material in the form of theories and examples of what will be given to students. Training for students of the Dharma Pembangunan Scholarship Institute was carried out online because there were still obstacles to the corona virus pandemic (Covid19). It is hoped that with this training students can understand how to determine the cost of goods sold in a manufacturing company. The activity ended with making SENAPENMAS articles as mandatory outputs, articles in the PINTAR media as additional outputs, posters, final reports, and financial reports on activities that had been carried out.
\end{abstract}

Keywords: Dharma Pembangunan Scholarship Institute, Cost of Goods Sold

\begin{abstract}
ABSTRAK
Permasalahan yang dihadapi oleh mitra yaitu Lembaga Beasiswa Dharma Pembangunan adalah para siswa siswi belum memahami secara mendalam topik mengenai penentuan harga pokok penjualan padahal untuk perusahaan dagang dan perusahaan manufaktur, penentuan harga pokok penjualan sangatlah penting. Dosen Fakultas Ekonomi dan Bisnis Universitas Tarumanagara menawarkan solusi dengan memberikan pelatihan mengenai penentuan cost of goods sold di perusahaan dagang, penentuan biaya produk, penentuan total biaya manufaktur, penentuan cost of goods manfactured, dan penentuan cost of goods sold di perusahaan manufaktur. Target pelatihan ini adalah agar siswa siswi Lembaga Beasiswa Dharma Pembangunan dapat memahami penentuan cost of goods sold di perusahaan dagang dan manufaktur. Pertama-tama dilakukan survei terlebih dahulu dan berdasarkan survei, mitra meminta agar dapat dibahas materi mengenai penentuan cost of goods sold di perusahaan dagang dan manufaktur. Topik kali ini ialah kelanjutan dari kegiatan pengabdian kepada masyarakat sebelumnya. Siswa siswi sudah pernah mendapatkan topik yang berbeda dari pelatihan sebelumnya. Selanjutnya dosen mempersiapkan materi berupa teori maupun contoh soal yang akan diberikan kepada para siswa siswi. Pelatihan ke siswa siswi Lembaga Beasiswa Dharma Pembangunan dilakukan secara online dikarenakan masih ada kendala pandemi virus corona (Covid-19). Diharapkan dengan adanya pelatihan ini siswa siswi dapat memahami bagaimana menentukan harga pokok penjualan di perusahaan manufaktur. Kegiatan diakhiri dengan membuat artikel SENAPENMAS sebagai luaran wajib, artikel di media PINTAR sebagai luaran tambahan, poster, laporan akhir, dan laporan keuangan atas kegiatan yang telah dilakukan.
\end{abstract}

Kata Kunci: Lembaga Beasiswa Dharma Pembangunan, Harga Pokok Penjualan 


\section{PENDAHULUAN}

Lembaga Beasiswa Dharma Pembangunan (LBDP) ialah yayasan yang bergerak dalam beasiswa pendidikan bagi siswa siswi yang kurang mampu dan berprestasi secara akademik, beragama Buddha. LBDP yang berlokasi di Jl. Sawah Lio 2 Gang 5 No. 55c, RT 10, RW 8, Jakarta Barat hanya dikhususkan untuk siswa siswi Sekolah Menengah Atas/Kejuruan $(\mathrm{SMA} / \mathrm{K})$ atau sederajat. Mayoritas siswa siswi Lembaga Beasiswa Dharma Pembangunan menempuh pendidikan Sekolah Menengah Atas/Kejuruan (SMA/K) atau sederajat di SMA Tri Ratna dan SMA Dhammasavana.

LBDP memberikan beasiswa kepada para siswa siswi yang berasal dari daerah di luar Jakarta. Beasiswa ini bersifat regenerasi, dalam arti siswa siswi yang telah menyelesaikan studi di $\mathrm{SMA} / \mathrm{K}$ atau sederajat tidak akan mendapatkan beasiswa lagi dan apabila siswa siswi tidak mendapatkan pekerjaan di Jakarta, maka siswa siswi diharapkan pulang dan membangun kampung halamannya. Siswa siswi Lembaga Beasiswa Dharma Pembangunan dapat melanjutkan kuliah di universitas swasta atau negeri namun dengan mencari beasiswa sendiri atau dapat juga meminta bantuan kepada pihak Lembaga Beasiswa Dharma Pembangunan.

Berikut adalah beberapa prestasi yang telah dicapai oleh siswa siswi Lembaga Beasiswa Dharma Pembangunan.

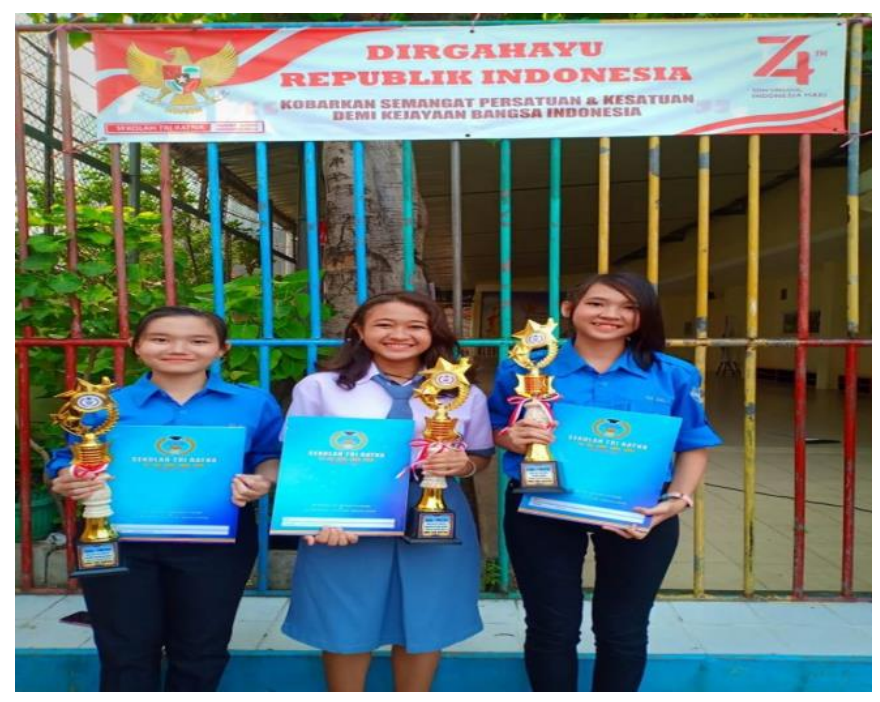

Foto di atas menunjukkan siswa siswi Lembaga Beasiswa Dharma Pembangunan yang bersekolah di SMA Tri Ratna. Ketiga siswa siswi tersebut mendapat beasiswa bebas Sumbangan Pembinaan Pendidikan (SPP). Beasiswa tersebut diperoleh berdasarkan prestasi akademik yang dicapai oleh siswa siswi. 


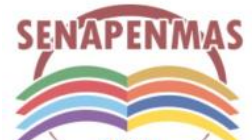

2021
Seminar Nasional Hasil Penelitian dan Pengabdian Kepada Masyarakat 2021 Pengembangan Ekonomi Bangsa Melalui Inovasi Digital Hasil Penelitian dan Pengabdian Kepada Masyarakat Jakarta, 21 Oktober 2021

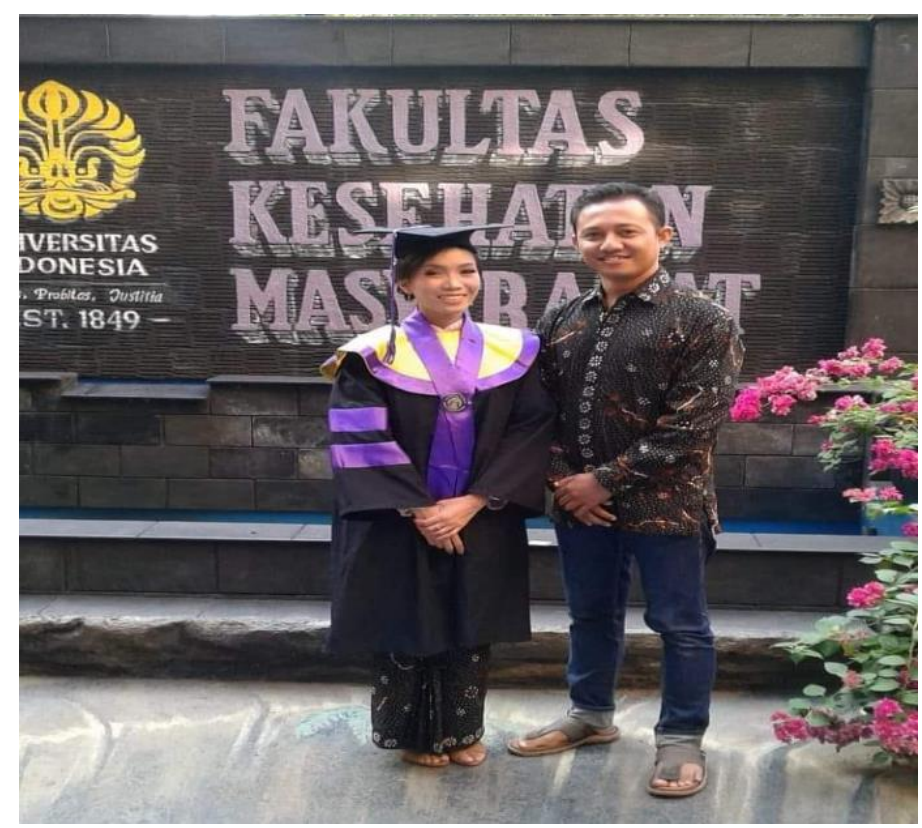

Foto di atas menunjukkan foto wisuda salah satu alumni dan pengurus aktif di Lembaga Beasiswa Dharma Pembangunan yang berhasil menyelesaikan studinya pada tahun 2019 di universitas terkemuka di Depok.

Para siswa siswi yang sudah menyelesaikan studinya juga tidak melupakan Lembaga Beasiswa Dharma Pembangunan yang sudah memberikan kesempatan untuk melanjutkan studi. Salah satu cara yang biasanya dilakukan adalah memberikan pelatihan atau tutorial atau les secara gratis kepada adik-adik yang masih bersekolah yang memperoleh beasiswa dari Lembaga Beasiswa Dharma Pembangunan.

Sebelumnya siswa siswi sudah pernah mendapatkan topik yang berbeda dari pelatihan sebelumnya, dan topik kali ini merupakan follow up untuk aktivitas pengabdian kepada masyarakat selanjutnya. Setelah dilakukan survei ke Lembaga Beasiswa Dharma Pembangunan, maka diketahui bahwa siswa siswi belum memahami secara mendalam topik mengenai penentuan cost of goods sold padahal penentuan harga pokok penjualan sangatlah penting untuk perusahaan dagang dan perusahaan manufaktur. Perusahaan dagang ialah perusahaan yang melakukan pembelian dan kemudian melakukan penjualan produk berwujud tanpa mengubah bentuk dasar atau aslinya. Biasanya perusahaan ini menjual produknya secara eceran. Contoh: supermarket, toko buku dan alat tulis, toko grosir, department store, dan lain sebagainya. Perusahaan manufaktur idalah perusahaan yang membeli bahan baku dan komponennya, lalu mengubah bahan mentah menjadi bermacam produk jadi yang siap dijual. Contoh: perusahaan otomotif yang membuat kendaraan, perusahaan tekstil yang membuat pakaian, perusahaan pengolah makanan, dan lain sebagainya.

Menurut Dewi dan Kristanto (2015) kegiatan perusahaan dagang tidak sama dengan perusahaan manufaktur. Kegiatan utama perusahaan dagang yaitu melakukan pembelian barang lalu menjualnya kembali dengan tidak mengubah bentuk dasarnya ataupun menambah manfaat dari barang tersebut. Kegiatan utama perusahaan manufaktur yaitu melakukan pembelian bahan dan komponen, lalu berikutnya mengubah bahan mentah menjadi barang jadi.

Menurut Dewi dan Kristanto (2015) jenis rekening yang akan disajikan dalam laporan posisi keuangan dan laporan laba rugi tidak sama. Perusahaan manufaktur juga wajib menyusun cost of production report. Perbedaan ada dua yaitu: 
Pertama, perbedaan yang terletak pada perhitungan harga pokok penjualan. Pada perusahaan dagang, barang tersedia dijual diperoleh dengan cara menjumlahkan persediaan awal barang dagang dan pembelian bersih. Pada perusahaan manufaktur, barang tersedia dijual diperoleh dengan cara menjumlahkan persediaan awal barang jadi dan harga pokok produksi.

Perbedaan kedua terletak pada laporan posisi keuangan. Perusahaan dagang hanya memiliki persediaan barang dagang, sedangkan perusahaan manufaktur memiliki persediaan bahan baku, persediaan bahan penolong, persediaan barang dalam proses, dan persediaan barang jadi.

Hal-hal yang perlu diperhatikan dalam menentukan cost of goods sold di perusahaan manufaktur yaitu:

1. Penentuan cost of goods sold di perusahaan dagang.

Menurut Dewi et al. (2017) ada dua sistem pencatatan persediaan. Pertama, sistem pencatatan perpetual yaitu sistem pencatatan dimana setiap kali terjadi transaksi pembelian dan penjualan barang dagang, maka perusahaan akan mencatat ke dalam akun persediaan barang dagang secara terus menerus. Perusahaan mencatat harga pokok persediaan barang dagang yang dibeli dan dijual secara rinci. Semua transaksi yang memengaruhi perkiraan persediaan barang dagang seperti retur dan potongan pembelian, diskon pembelian, dan ongkos angkut masuk akan dicatat langsung ke perkiraan persediaan barang dagang. Barang dagang yang masuk maupun yang keluar akan langsung dicatat oleh perusahaan ke dalam perkiraan persediaan barang dagang. Dengan demikian pada akhir periode dapat diketahui nilai persediaan barang dagang, yaitu dengan cara menjumlahkan semua perkiraan persediaan barang dagang. Perusahaan akan mencatat pendapatan serta menghitung dan mencatat harga pokok penjualan setiap kali terjadi transaksi penjualan.

Kedua, sistem pencatatan periodik yaitu sistem pencatatan dimana jika perusahaan melakukan pembelian barang dagang maka akan dicatat ke perkiraan pembelian dan jika perusahaan melakukan penjualan barang dagang maka akan dicatat ke perkiraan penjualan tanpa memengaruhi perkiraan persediaan barang dagang. Perusahaan tidak melakukan pencatatan harga pokok dari persediaan barang dagang secara rinci. Hal ini dikarenakan catatan mengenai persediaan tidak dibuat sepanjang periode. Perusahaan tidak mencatat pembelian, diskon pembelian, potongan dan retur pembelian, dan ongkos angkut masuk secara langsung ke perkiraan persediaan barang dagang namun perusahaan mencatat ke perkiraan tersendiri. Pendapatan akan dicatat setiap kali terjadi transaksi penjualan, tetapi perhitungan harga pokok penjualan baru akan dilakukan di akhir periode akuntansi. Nilai akhir persediaan barang dagang akan diketahui dengan cara melakukan perhitungan fisik terhadap jenis dan jumlah barang yang tersedia pada akhir periode akuntansi. Menurut Weygandt et al. (2016) cara perusahaan dagang menentukan cost of goods sold ialah:

Persediaan finished goods awal

Pembelian kotor

Potongan dan retur pembelian

Diskon pembelian

Pembelian bersih

Ongkos angkut masuk

Harga pokok pembelian

Persediaan yang tersedia untuk dijual

Persediaan finished goods akhir

Harga pokok penjualan
XX

$\mathrm{XX}$

$(\mathrm{xx})$

$\underline{(\mathrm{xx})}$

$\mathrm{xx}$

$\underline{\mathrm{XX}}$ 
2. Penentuan biaya bahan mentah.

Menurut Vanderbeck dan Mitchell (2016) biaya bahan mentah merupakan biaya yang bisa ditelusuri ke objek biaya dengan cara yang ekonomis. Biaya bahan mentah merupakan biaya perolehan semua bahan yang pada akhirnya akan menjadi barang dalam proses dan barang jadi. Contohnya adalah kain adalah bahan baku pada sebuah baju dan karet pada sebuah sepatu.

\section{Penentuan biaya upah langsung.}

Menurut Dewi dan Kristanto (2015) biaya upah langsung merupakan biaya yang dibayarkan ke karyawan atau tenaga kerja yang terlibat secara langsung dalam proses pengubahan bahan baku menjadi barang jadi. Biaya tenaga kerja langsung terdiri dari kompensasi atas seluruh tenaga kerja manufaktur yang bisa ditelusuri ke barang dalam proses dan barang jadi dengan cara yang ekonomis. Contohnya adalah koki dalam sebuah restoran, tukang jahit pada pabrik garmen, dan tukang kayu pada pabrik furnitur.

\section{Penentuan biaya manufaktur pabrik atau biaya produksi tidak langsung.}

Menurut Carter et al. (2015) biaya manufaktur pabrik merupakan seluruh biaya manufaktur yang terkait dengan objek biaya namun tidak bisa ditelusuri ke barang dalam proses dan barang jadi dengan cara yang ekonomis. Contohnya adalah biaya tenaga kerja tidak langsung (misal: upah satpam pabrik, petugas kebersihan pabrik, upah mandor, dan gaji manajer pabrik), biaya bahan baku penolong (misal: pelumas, bahan pembersih), dan beban-beban yang muncul di pabrik.

5. Penentuan total biaya manufaktur.

Menurut Suriani dan Lesmana (2020) salah satu biaya terbesar yang harus dikorbankan oleh perusahaan ialah biaya produksi atau biaya produk atau total biaya manufaktur. Biaya produk merupakan merupakan bagian dari persediaan dan biaya ini bisa dikaitkan dengan suatu produk. Menurut Dewi dan Kristanto (2015) total biaya manufaktur merupakan biaya yang terkait langsung dengan transfer barang ke lokasi pembeli dan pengubahan barang tersebut ke kondisi yang siap dijual.

\section{Penentuan harga pokok produksi.}

Menurut Dewi dan Kristanto (2015) harga pokok produksi merupakan biaya barang yang dibeli oleh perusahaan untuk diproses sampai selesai, baik sebelum maupun selama periode akuntansi berjalan. Semua biaya harga pokok produksi adalah biaya persediaan dimana semua biaya produk yang dianggap sebagai aset dalam laporan posisi keuangan ketika terjadi maka selanjutnya akan menjadi harga pokok penjualan ketika produk tersebut dijual. Menurut Satriani dan Kusuma (2020) unsur-unsur yang ada di harga pokok produksi yaitu biaya pabrikasi yang terdiri atas biaya bahan baku, biaya tenaga kerja, biaya overhead pabrik, dan persediaan barang dalam proses baik persediaan barang dalam proses awal maupun persediaan barang dalam proses akhir.

7. Penentuan harga pokok penjualan di perusahaan manufaktur.

Menurut Lanen et al. (2014) cara menentukan harga pokok penjualan di perusahaan manufaktur ialah:

Direct material yang digunakan:

Persediaan direct material awal

Pembelian direct material bersih

Direct material yang tersedia untuk digunakan

$\underline{\mathrm{xx}}$

Persediaan direct material akhir

$\mathrm{xX}$

Direct material yang digunakan 
Gaji upah langsung

$\mathrm{XX}$

Manufaktur pabrik:

Bahan pelengkap $\quad$ xx

Gaji mandor pabrik dan satpam pabrik $\quad \mathrm{xx}$

Beban penyusutan peralatan dan gedung pabrik $\mathrm{xx}$

Pemakaian energi pabrik $\quad x x$

Asuransi gedung dan peralatan pabrik $\quad \mathrm{xx}$

Beban overhead pabrik lain-lain $\quad \underline{x x}$

Total overhead pabrik

Total biaya manufaktur

Work in process awal

Work in process akhir

Harga pokok produksi

Finished goods awal

Finished goods akhir

Harga pokok penjualan

$\begin{array}{cc}\underline{\mathrm{Xx}} & \\ \mathrm{xx} & \underline{\mathrm{xx}} \\ \underline{(\mathrm{xx})} & \\ & \mathrm{xx} \\ & \mathrm{xx} \\ & \frac{(\mathrm{xx})}{\mathrm{xx}}\end{array}$

Permasalahan yang dihadapi antara lain ialah para siswa siswi belum memahami secara mendalam topik mengenai:

1. Penentuan cost of goods sold di perusahaan dagang.

2. Penentuan biaya bahan mentah.

3. Penentuan biaya upah langsung.

4. Penentuan biaya produksi tidak langsung.

5. Penentuan total biaya manufaktur.

6. Penentuan cost of goods manufactured.

7. Penentuan cost of goods sold di perusahaan manufaktur.

\section{METODE PELAKSANAAN PKM}

Berdasarkan pada permasalahan yang dihadapi oleh mitra, maka dosen Fakultas Ekonomi dan Bisnis Universitas Tarumanagara menawarkan solusi yaitu memberikan pelatihan mengenai bagaimana menentukan harga pokok penjualan di perusahaan dagang, bagaimana menentukan biaya bahan mentah, bagaimana menentukan biaya upah langsung, bagaimana menentukan biaya produksi tidak langsung, bagaimana menentukan total biaya manufaktur, bagaimana menentukan cost of goods manufactured, dan bagaimana menentukan cost of goods sold di perusahaan manfaktur.

Tahapan metode yang digunakan adalah:

1. Pertama-tama akan dijelaskan terlebih dahulu mengenai teori atau konsep yang berhubungan dengan perusahaan dagang dan perusahaan manufaktur.

2. Selanjutnya dosen akan memberikan contoh soal yang terkait dengan bagaimana menentukan harga pokok penjualan di perusahaan dagang, bagaimana menentukan biaya bahan mentah, bagaimana menentukan biaya upah langsung, bagaimana menentukan biaya produksi tidak langsung, bagaimana menentukan total biaya manufaktur, bagaimana menentukan cost of goods manufactured, dan bagaimana menentukan cost of goods sold di perusahaan manufaktur.

Mitra akan menyediakan tempat pelatihan dan memberikan jadwal pelatihan untuk disesuaikan dengan jadwal dosen. Selain itu, mitra juga diminta untuk menentukan jumlah personil yang akan diberikan pelatihan sesuai dengan jadwal yang telah disepakati bersama. 


\section{HASIL DAN PEMBAHASAN}

Di akhir periode akuntansi, cara perusahaan dagang menentukan cost of goods sold adalah dengan menjumlahkan persediaan barang dagang awal dengan harga pokok pembelian (pembelian kotor ditambah ongkos angkut masuk lalu dikurangi diskon pembelian serta retur dan potongan pembelian) untuk mendapatkan persediaan yang tersedia untuk dijual. Selanjutnya persediaan yang tersedia untuk dijual dikurangi dengan persediaan barang dagang akhir untuk mendapatkan harga pokok penjualan.

Tidak seperti perusahaan dagang, harga pokok penjualan di perusahaan manufaktur ditentukan dengan cara menjumlahkan biaya bahan mentah, biaya upah langsung, dan biaya biaya produksi tidak langsung guna memperoleh total biaya manufaktur. Setelahnya total biaya manufaktur ditambah dengan barang dalam proses awal dan dikurangi dengan barang dalam proses akhir guna memperoleh harga pokok produksi. Terakhir harga pokok produksi ditambah dengan barang jadi awal dan dikurangi dengan barang jadi akhir guna memperoleh harga pokok penjualan.

Sebelum memberikan pelatihan, dosen Fakultas Ekonomi dan Bisnis Universitas mengadakan sosialisasi terlebih dahulu ke Lembaga Beasiswa Dharma Pembangunan pada hari Sabtu tanggal 24 Juli 2021. Setelah mengadakan sosialisasi, dosen menyusun materi yang akan diberikan kepada peserta pelatihan dan mempersiapkan semua perlengkapan yang akan diberikan saat pelatihan.

Pelatihan dilakukan pada tanggal 28 Agustus 2021 dan pada tanggal 18 September 2021. Pada pelatihan hari pertama, yaitu hari Sabtu tanggal 28 Agustus 2021 dosen akan menerangkan teori atau konsep yang terkait dengan perusahaan dagang dan perusahaan manufaktur. Pelatihan kedua yaitu hari Sabtu tanggal 18 September 2021 dosen memberikan contoh soal bagaimana menentukan harga pokok penjualan di perusahaan dagang, bagaimana menentukan biaya bahan mentah, bagaimana menentukan biaya upah langsung, bagaimana menentukan biaya produksi tidak langsung, bagaimana menentukan total biaya manufaktur, bagaimana menentukan cost of goods manufactured, dan bagaimana menentukan cost of goods sold di perusahaan manufaktur.

Sebagai upaya mendukung penekanan penyebaran virus, dosen tidak ke lokasi mitra namun memberikan pelatihan secara tatap muka kepada siswa siswi Lembaga Beasiswa Dharma Pembangunan. Sebagai bentuk tanggungjawab kepada mitra, dosen akhirnya memutuskan tetap memberikan pelatihan secara online melalui ZOOM. Berikut adalah dokumentasi yang dilakukan selama pelaksanaan kegiatan.

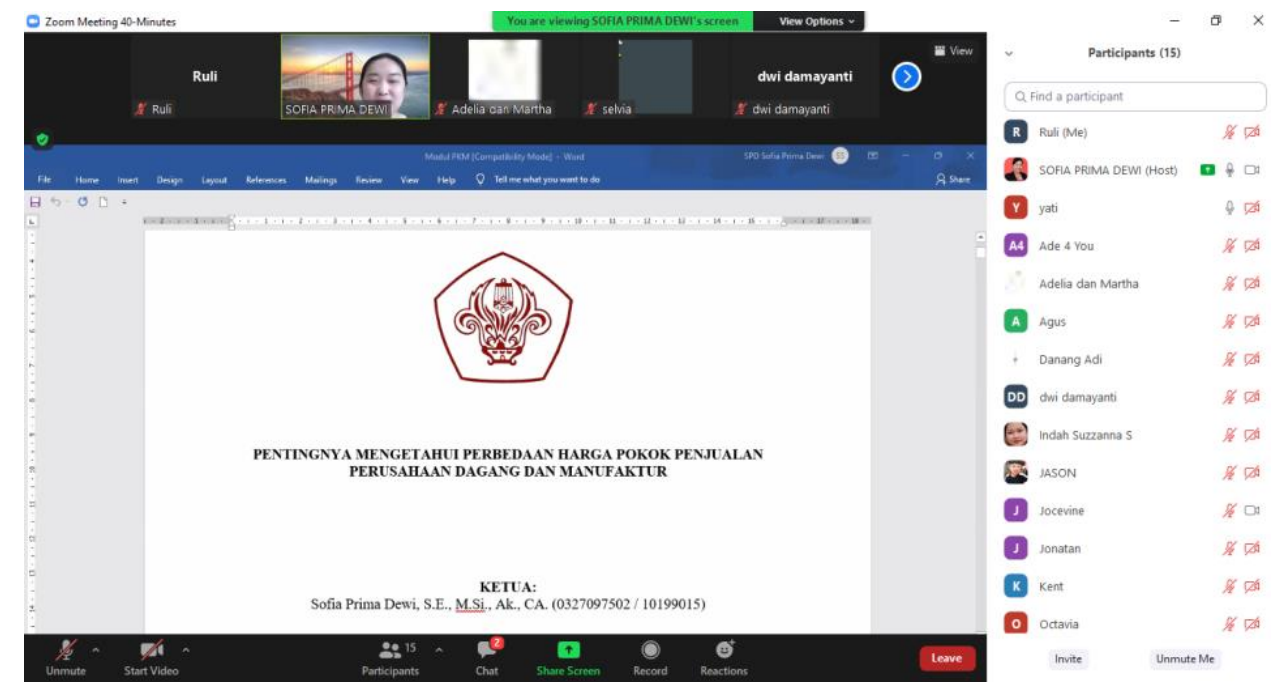


Hasil yang dicapai adalah siswa siswi Lembaga Beasiswa Dharma Pembangunan dapat memahami topik mengenai bagaimana menentukan harga pokok penjualan di perusahaan dagang, bagaimana menentukan biaya bahan mentah, bagaimana menentukan biaya upah langsung, bagaimana menentukan biaya produksi tidak langsung, bagaimana menentukan total biaya manufaktur, bagaimana menentukan cost of goods manufactured, dan bagaimana menentukan cost of goods sold di perusahaan manufaktur.

\section{KESIMPULAN DAN SARAN}

Pelatihan ini bertujuan adalah agar siswa siswi Lembaga Beasiswa Dharma Pembangunan dapat memahami topik mengenai bagaimana menentukan harga pokok penjualan di perusahaan dagang, bagaimana menentukan biaya bahan mentah, bagaimana menentukan biaya upah langsung, bagaimana menentukan biaya produksi tidak langsung, bagaimana menentukan total biaya manufaktur, bagaimana menentukan cost of goods manufactured, dan bagaimana menentukan cost of goods sold di perusahaan manufaktur.

Atas dasar hasil survei, diketahui bahwa siswa siswi Lembaga Beasiswa Dharma Pembangunan belum memahami secara mendalam topik mengenai penentuan cost of goods sold padahal penentuan cost of goods sold sangat penting bagi perusahaan dagang dan perusahaan manufaktur. Situasi pandemi virus corona (Covid-19) mengakibatkan dosen tidak dapat datang ke lokasi mitra sehingga pelatihan diberikan secara online melalui ZOOM.

Berdasarkan hasil pembicaraan dengan kepala sekolah dan siswa siswi Lembaga Beasiswa Dharma Pembangunan, diharapkan pelatihan seperti ini diadakan Kembali namun dengan topik yang berbeda, yang belum diperoleh dari sekolah agar bisa menambah wawasan mereka saat melanjutkan jenjang pendidikan selanjutnya.

\section{Ucapan Terima Kasih (Acknowledgement)}

Kami mengucapkan terima kasih kepada semua pihak yang telah mendukung terlaksananya kegiatan pelatihan yang kami lakukan, yaitu: Rektor Universitas Tarumanagara, Ketua Lembaga Penelitian dan Pengabdian Kepada Masyarakat Universitas Tarumanagara, Dekan dan segenap pimpinan Fakultas Ekonomi dan Bisnis Universitas Tarumanagara, Lembaga Beasiswa Dharma Pembangunan, serta semua pihak yang tidak dapat kami sebutkan satu per satu.

\section{REFERENSI}

Carter, W. K., Hwang, J. F., \& Chow, S. T. (2015). Cost Accounting. An Asia Edition. Singapore: Cengage Learning Asia Pte Ltd.

Dewi, S. P., Dermawan E. S., \& Susanti, M. (2017). Pengantar Akuntansi. Sekilas Pandang Perbandingan dengan SAK yang mengadopsi IFRS, SAK ETAP, dan SAK EMKM. Edisi Pertama. Bogor: In Media.

Dewi, S. P., \& Kristanto, S. B. (2015). Akuntansi Biaya. Edisi Kedua. Bogor, In Media.

Lanen, W. N., Anderson, S. W., \& Maher, M. W. (2014). Fundamental of Cost Accounting. Fourth Edition. USA: McGraw-Hill Companies, Inc.

Satriani, D., \& Kusuma, V. V. (2020). Perhitungan Harga Pokok Produksi Dan Harga Pokok Penjualan Terhadap Laba Penjualan. Jurnal Ilmiah MEA (Manajemen, Ekonomi, dan Akuntansi, 4(2), 438-453.

Suriani, \& Lesmana, A. (2020). Analisis Harga Pokok Penjualan dan Biaya Produksi Terhadap Laba Kotor (Studi Kasus Pada PT Gajah Tunggal Tbk Tahun 2015-2018). Jurnal Riset Akuntansi dan Bisnis, 6(2), 134-145.

Vanderbeck, E. J., \& Mitchell, M. R. (2016). Principles of Cost Accounting. Seventeenth Edition. Boston: Cengage Learning. 


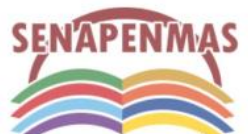

2021
Seminar Nasional Hasil Penelitian dan Pengabdian Kepada Masyarakat 2021

Pengembangan Ekonomi Bangsa Melalui Inovasi Digital Hasil Penelitian dan Pengabdian Kepada Masyarakat Jakarta, 21 Oktober 2021

Weygandt, J. J., Kimmel, P. D., \& Kieso, D. E. (2016). Accounting Principles. Twelfth Edition. United States of Amerika: John Wiley and Sons, Inc. 
Seminar Nasional Hasil Penelitian dan Pengabdian Kepada Masyarakat 2021

Pengembangan Ekonomi Bangsa Melalui Inovasi Digital Hasil Penelitian dan

Pengabdian Kepada Masyarakat

Jakarta, 21 Oktober 2021

(halaman kosong) 